\title{
Combination Effect of Systemic Hypothermia and Caspase Inhibitor Administration against Hypoxic-Ischemic Brain Damage in Neonatal Rats
}

\author{
MASAO ADACHI, OSAMU SOHMA, SHUICHI TSUNEISHI, SATOSHI TAKADA, AND \\ HAJIME NAKAMURA \\ Department of Pediatrics, Kobe University School of Medicine, Kobe, Japan
}

\begin{abstract}
Caspases are believed to play a key role in the delayed neuronal cell death observed in the rat brain after hypoxicischemic (HI) insult. Caspase inhibitors have been developed as antiapoptotic agents. Hippocampal damage after HI insult is strongly related to tissue temperature, and systemic hypothermia has been introduced clinically for brain protection. In this study, we examined the effects of a caspase inhibitor and systemic hypothermia on neuronal protection in the developing rat brain. Postnatal d 7 rat pups were subjected to the Rice model of hypoxia for $1 \mathrm{~h}$. Systemic hypothermia was induced with a water bath at $29^{\circ} \mathrm{C}$. Before $\mathrm{HI}$ insult, a pan-caspase inhibitor, bocaspartyl-(OMe)-fluoromethyl-ketone (BAF), was injected into the cerebral ventricle. The ipsilateral hippocampus was subjected to caspase assays and histologic assessment. The HI group at $37^{\circ} \mathrm{C}\left(\mathrm{HI}-37^{\circ} \mathrm{C}\right)$ showed a peak of caspase- 3 activity $16 \mathrm{~h}$ after insult. This activity was significantly reduced in the presence of BAF or hypothermia $\left(\mathrm{HI}-29^{\circ} \mathrm{C}\right.$ group, $\left.p<0.05\right)$ or by the combination of $\mathrm{HI}-29^{\circ} \mathrm{C}+\mathrm{BAF}\left(p<0.01\right.$ versus $\left.\mathrm{HI}-37^{\circ} \mathrm{C}\right)$. The number of neuronal cells in the ipsilateral hippocampal CA1
\end{abstract}

\section{ABSTRACT}

region in the $\mathrm{HI}-37^{\circ} \mathrm{C}$ group was significantly decreased $(62.9 \%$ versus control). The number of neuronal cells was maintained in the $\mathrm{HI}-37^{\circ} \mathrm{C}+\mathrm{BAF}$ group $(82.7 \%)$, the $\mathrm{HI}-29^{\circ} \mathrm{C}$ group $(78.7 \%)$, and the combination group $(95.2 \%)\left(p<0.05\right.$ versus $\left.\mathrm{HI}-37^{\circ} \mathrm{C}\right)$. A combination of systemic hypothermia and BAF produced a strong protective effect against neuronal damage in the developing rat brain, along with a reduction in caspase-3 activity. (Pediatr Res 50: 590-595, 2001)
Abbreviations
DNCD, delayed neuronal cell death
PCD, programmed cell death
PD, postnatal day
HI, hypoxia and ischemia
Ac-DEVD-MCA, Ac-Asp-Glu-Val-Asp-MCA
BAF, boc-aspartyl-(OMe)-fluoromethyl-ketone
ICV, intracerebroventricular
f-DNA, fragmented DNA

Investigators have recently reported that transient $\mathrm{HI}$ induces not only acute brain damage but also DNCD in selected regions such as the hippocampus, striatum, and pons in human and animal brains $(1,2)$. DNCD is characteristically observed 3-5 $\mathrm{d}$ after insult. Others have reported that DNCD displays characteristics of PCD $(3,4)$. Some of the morphologic features observed in PCD, such as condensation of nuclear chromatin, cytoplasmic shrinkage without inflammatory reaction, dilated endoplasmic reticulum, membrane blebbing, and formation of apoptotic bodies, are characteristic of apoptosis $(3,5)$. Apoptotic PCD plays an important role in animal and human models of various diseases, such as ischemic brain damage (3, $5,6)$, traumatic brain injury $(7,8)$, neurodegenerative diseases

Received October 4, 2000; accepted June 1, 2001.

Correspondence and reprint requests: Satoshi Takada, M.D., Department of Pediatrics, Kobe University School of Medicine, 7-5-1, Kusunoki-cho, Chuo-ku, Kobe, Hyogo, 650-0017, Japan; e-mail: ama-p@rc4.so-net.ne.jp

Supported, in part, by a Grant-Aid for Scientific Research (No. 11671069) from the Ministry of Education.
(9-12), CNS infection (13), and epilepsy (14-16). Many reports have also revealed biochemical and genetic events that accompany apoptotic cell death. One of these events is the activation of a specific family of cysteine proteases, caspases, that precede the occurrence of DNA fragmentation, which also occurs in apoptosis $(17,18)$. In brief, caspases are synthesized in most cells as inactive precursors (pro-caspases) and are activated to form active caspases. Caspase-3, a terminal player in the caspase family, activates an endonuclease (caspase-activated DNAse, or CAD) to induce the fragmentation of DNA (4).

Recently, various caspase inhibitors have been developed. Some investigators have attempted to prevent the neuronal damage with these inhibitors in vivo, occurring in acute bacterial meningitis in rabbits (13), status epilepticus in rats (15), and hypoxic ischemic brain damage in rats $(17,19-21)$ and gerbils (22). In all these reports, neuronal damage was significantly less in treated animals than in untreated ones.

It is well known that neuronal cell death in some brain regions such as the striatum and hippocampus is selectively 
influenced by tissue temperature. Several researchers have reported that hypothermia during ischemia reduces brain damage in experimental animals (23-27). For example, intraischemic hypothermia prevented hippocampal CA1 neurons from transient global ischemic damage and inhibited the fragmentation of DNA (23). Other researchers noted that mild intra-ischemic hypothermia can exert neuroprotection against brain damage, especially in immature animals (28-31). These reports suggest that there is a significant correlation between the severity of brain damage and the degree of hypothermia during the insult. A $3^{\circ} \mathrm{C}$ reduction of systemic temperature during $\mathrm{HI}$ insult was reported to partially protect the brain, and a $6^{\circ} \mathrm{C}$ reduction protected completely against damage $(30,31)$. In the hippocampus, a small increase in body temperature during $\mathrm{HI}$ insult resulted in an expansion of damaged area and damage severity in experimental animals (25).

In contrast to any reports of insufficient effect of postischemic hypothermia on brain damage in adult animals $(24,27)$, several recent reports showed that postischemic hypothermia reduced brain damage associated with $\mathrm{HI}$ in immature animals $(31,32)$. Thoresen's group (32) in Europe reported that postischemic mild hypothermia improved both short- and longterm neurologic outcome associated with $\mathrm{HI}$ in neonatal rats.

According to some findings described above, a combination of caspase inhibitor and hypothermia may have more synergistic or additive effect against brain damage associated with $\mathrm{HI}$ than each individual administration. Hence, in the present study, the effect of a combination of caspase inhibitor administration and systemic hypothermia during $\mathrm{HI}$ insult in the developing rat brain was assessed with biochemical (caspase assay), histologic (neuronal cell count), and molecular (DNA electrophoresis) methods.

\section{MATERIALS AND METHODS}

Materials and animals. Sprague-Dawley (SD) rat pups were purchased from Japan SLC (Shizuoka, Japan). All pups were unsexed, and their mean body weight was $10-14 \mathrm{~g}$ on PD 7 . All animal experiments were performed using the highest standards of animal care and housing according to the National Institutes of Health Guide for the Care and Use of Laboratory Animals.

The caspase inhibitor, boc-aspartyl-(OMe)-fluoromethyl ketone (BAF), was purchased from Enzyme Systems Products (Livermore, CA, U.S.A.). This lipophilic peptide is permeable to the cell membrane and a pan-caspase inhibitor (33).

Hypoxia-ischemia. A model of HI based on Rice's procedure (34) was performed on PD 7. Pups were anesthetized lightly with inhaled diethyl-ether, the left carotid artery was accessed through a midline incision, and surgical ligation was performed with a double suture (4.0 silk) and a permanent incision. The procedure was performed at room temperature $\left(23-25^{\circ} \mathrm{C}\right)$. After closure of the neck wound, pups were returned to their dams to feed for $2 \mathrm{~h}$. The entire surgical procedure lasted no longer than $10 \mathrm{~min}$, and pups experiencing technical difficulties were excluded from the study. The pups were then placed individually in airtight $500-\mathrm{mL}$ plastic chambers through which $8 \%$ humidified oxygen and balanced nitro- gen gas flowed for $1 \mathrm{~h}$ (variation of Rice's procedure). Thermal control was maintained by submerging the hypoxic chamber in a circulating water bath.

Systemic hypothermia. Systemic hypothermia $\left(29^{\circ} \mathrm{C}\right)$ and normothermia $\left(37^{\circ} \mathrm{C}\right)$ were induced by submerging the hypoxic chamber in a water bath at $29^{\circ} \mathrm{C}$ and $37^{\circ} \mathrm{C}$, respectively. Rectal temperature was also monitored (Small Animals Heat Controller, Unique Medical, Tokyo, Japan). After the hypothermic period, pups were quickly returned to their mothers and their body temperature was slowly elevated to normal $\left(35-37^{\circ} \mathrm{C}\right)$ within $1 \mathrm{~h}$.

ICV injection of caspase inhibitor. A $100 \mathrm{mM}$ stock solution of BAF was prepared in DMSO (final concentration of $0.2 \%$ ). On PD 7, rat pups were anesthetized lightly with diethyl-ether, and $5 \mu \mathrm{L}$ of solution containing $100 \mathrm{nM}$ BAF in PBS (pH 7.4) or PBS vehicle alone (VEH) was injected into the right cerebral ventricle transcranially with a microcapillary tube (Drummond PCR Micropipets 1-5 $\mu \mathrm{L}$, Birmingham, AL, U.S.A.) connected to a 5- $\mu \mathrm{L}$ Hamilton syringe and manipulator (NARISHIGE SR-5N, Narishige, Tokyo, Japan) as described previously (19). Injections were performed immediately before ligation. To control for histologic damage caused by inflammatory reaction in response to ICV injection in hippocampal tissue, all injection was performed into the contralateral ventricle. The location of each injection in relation to lambda was approximately $2.0 \mathrm{~mm}$ rostral, $1.5 \mathrm{~mm}$ lateral, and $2.0 \mathrm{~mm}$ deep to the skull surface, as described previously (35). The injected point on the skull and the incision were closed nonsurgically with adhesive agents, and the pups were subjected to the HI procedure.

Study design. The protocol for the present study is shown in Figure 1. After the surgical procedure and resting period, the rat pups were divided randomly into the following subgroups: the $\mathrm{HI}$ at $37^{\circ} \mathrm{C}$ group $\left(\mathrm{HI}-37^{\circ} \mathrm{C}\right)$, the pretreated with $\mathrm{BAF}$ and $\mathrm{HI}$ at $37^{\circ} \mathrm{C}$ group ( $\left.\mathrm{HI}-37^{\circ} \mathrm{C}+\mathrm{BAF}\right)$, the $\mathrm{HI}-29^{\circ} \mathrm{C}$ group, and the $\mathrm{HI}-29^{\circ} \mathrm{C}+\mathrm{BAF}$ group. Three assessment methods were used to compare the above groups with the control (CTL)- and vehicle (VEH)-treated groups (1). Caspase-3 cleavage activity was measured at $16 \mathrm{~h}$ after $\mathrm{HI}$ insult ( $n=9$ for each group) (2). The number of viable hippocampal CA1 neurons was counted at $7 \mathrm{~d}$ after HI insult $(n=6)$ (3). DNA fragmentation was detected by electrophoresis at $4 \mathrm{~d}$ after HI insult $(n=3 \times 3$ sets).

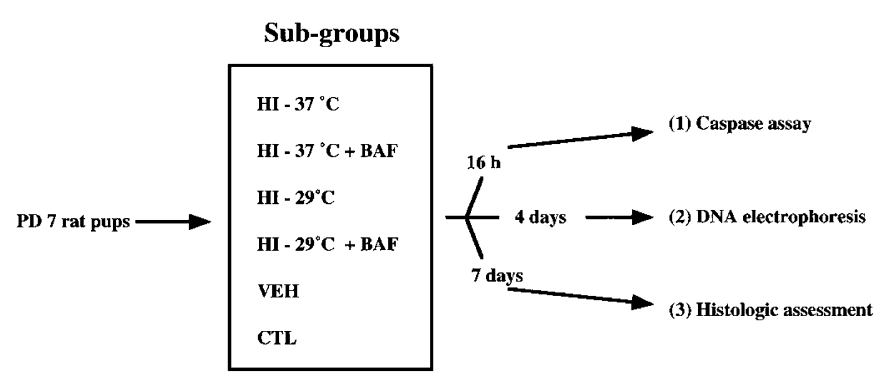

Figure 1. Study design and protocol for the present study. $H I-37^{\circ} \mathrm{C}+B A F$, hypoxia $(1 \mathrm{~h})$ and ischemia at $37^{\circ} \mathrm{C}$ after administration of BAF $(100 \mathrm{nmol}$ per animal); HI, hypoxia and ischemia; VEH, vehicle (PBS) without HI; CTL, sham-operated control; $16 h, 16 \mathrm{~h}$ after HI insult. 
Caspase cleavage assay. On the appropriate time and day, rat pups were perfused transcardially with cold PBS (pH 7.4), and hippocampal tissues were removed. Dissected hippocampal tissues were lysed in $4 \mathrm{~mL}$ buffer A $(250 \mathrm{mM}$ sucrose, 50 $\mathrm{mM} \mathrm{KCl}, 20 \mathrm{mM}$ HEPES-KOH, pH 7.4, $2.5 \mathrm{mM} \mathrm{MgCl}_{2}, 1$ $\mathrm{mM}$ DTT), homogenized, and centrifuged at $20,000 \times g$ for 30 min, and the lysate was collected. One hundred microliters of this cell lysate was subjected to enzymatic reaction with $3 \mu \mathrm{L}$ $100 \mathrm{mM}$ Ac-DEVD-MCA (a fluorogenic substrate peptide specific to caspase-3) solution for $15 \mathrm{~min}$ at $37^{\circ} \mathrm{C}$. The reaction was terminated with $50 \mu \mathrm{L}$ solution $\mathrm{B}\left(175 \mathrm{mM} \mathrm{CH}_{3} \mathrm{COOH}\right.$, $\left.1 \% \mathrm{CH}_{3} \mathrm{COONa} \cdot 3 \mathrm{H}_{2} \mathrm{O}\right)$. The fluorescent MCA product released by caspase- 3 was measured at an excitation wavelength of $380 \mathrm{~nm}$ and at an emission wavelength of $460 \mathrm{~nm}$ in the fluorescence plate reader (SIMADZU Double-Beam spectrophotometer UV-150-02, Kyoto, Japan) as described previously (34). Total protein was measured with Lowry's procedure (BIO-RAD DC Protein Assay Kit, Bio-Rad, Hercules, CA, U.S.A.). These experiments were performed in triplicate, and Ac-DEVD-MCA cleavage activity was presented as total relative fluorescent units per milligram protein per minute (Units/mg protein/min). To assess the time course for alteration in caspase-3 activity, measurement were made at $0,8,16,24$, and $40 \mathrm{~h}$, and 4 and $7 \mathrm{~d}$ after $\mathrm{HI}$ insult $(n=9)$. We selected the time point of $16 \mathrm{~h}$ after $\mathrm{HI}$ insult, when activity was significantly increased compared with CTL, to examine the effect of BAF pretreatment on caspase-3 activity.

CA1 neuronal cell count. On PD 14 (7 d after HI insult), brains were removed and stored overnight in fixation buffer (4\% paraformaldehyde in PBS) at $4^{\circ} \mathrm{C}$. Coronal sections were prepared at the level of the hippocampus from paraffinembedded samples, and sections were stained with hematoxylin-eosin. Specimens were screened for apoptotic hallmarks, fragmented nuclei, basophilic cytoplasmic shrinkage, and formation of apoptotic bodies.

Hippocampal neuronal damage was assessed by counting the number of surviving cells based on the following method. Briefly, the number of morphologically normal, viable neuronal cells in the CA1 region of the ipsilateral hippocampus was counted with 400x power magnification light microscope connected to a personal computer (PC). Randomly selected fields were imported with a digital camera (Fujix HC-300Z) and software (Photograb-300Z, FUJIFILM, Tokyo, Japan) and cell counting was performed by marking cells on the PC monitor. Finally, total cell numbers were summed across three separate fields (total $30,000 \mu \mathrm{m}^{2}$ ). The data are presented as the mean neuronal cell count per field.

Analysis of DNA fragmentation. The effect of systemic hypothermia and BAF on DNCD morphologic features was examined by electrophoretic detection of f-DNA. Tissues from the ipsilateral hippocampus were harvested at $0,16,24$, and $40 \mathrm{~h}$ and 3, 5, and $7 \mathrm{~d}$ after $\mathrm{HI}$ insult (three samples were pooled as a set for each subgroup). This analysis was performed three times at each time point. DNA was isolated with the Wizard Genomic DNA Purification Kit (Promega, Madison, WI, U.S.A.) according to manufacturer's instructions. Isolated DNA was electrophoresed on a $2 \%$ agarose gel in the presence of $0.2 \mathrm{mg} / \mathrm{mL}$ ethidium bromide and visualized with a UV illuminator. f-DNA was detected as a ladder of bands consisting of multiple nucleosomes. Diffuse f-DNA associated with necrosis was visualized as a smear pattern. Apoptotic protection and necrotic protection were measured as a decrease in OD of the ladder of bands and the smear pattern individually.

Statistical analysis. All data are presented as mean \pm SD. Statistical analysis of the data included multifactorial ANOVA with Fisher's correction; $p<0.05$ was considered significant.

\section{RESULTS}

Monitoring of rectal temperature. In the $\mathrm{HI}-29^{\circ} \mathrm{C}$ group, the rectal temperature of $30^{\circ} \mathrm{C}$ during hypoxia was achieved immediately $\left(p<0.01\right.$ versus normothermia of $36-37^{\circ} \mathrm{C}$, data not shown). But with the administration of BAF, rectal temperature showed no significant differences from those of nontreated HI groups.

Alteration of caspase activity. Caspase- 3 activity in the HI-treated group gradually elevated before $8 \mathrm{~h}$ after insult, peaking at $8.32 \pm 1.72 \mathrm{Units} / \mathrm{mg}$ protein $/ \mathrm{min}$ at $16 \mathrm{~h}$ after insult (Fig. 2). This peak was significantly higher than that of the sham-operated control group (CTL, $2.74 \pm 0.56 \mathrm{Units} / \mathrm{mg}$ protein/min) $(p<0.01)$. The activity decreased to baseline by $40 \mathrm{~h}$. In contrast, the CTL group showed little alteration throughout the study period.

Effect of systemic hypothermia and caspase inhibitor. Caspase-3 activity $16 \mathrm{~h}$ after $\mathrm{HI}$ insult is presented in Table 1. In the systemic hypothermia group $\left(\mathrm{HI}-29^{\circ} \mathrm{C}\right)$, caspase- 3 activity was reduced significantly to $4.62 \pm 0.23$ Units $/ \mathrm{mg}$ protein $/ \mathrm{min} .\left(p<0.01\right.$ versus the $\mathrm{HI}-37^{\circ} \mathrm{C}$ group). In the $\mathrm{HI}-37^{\circ} \mathrm{C}+\mathrm{BAF}$ group, caspase activity was reduced significantly to $3.88 \pm 0.41 \mathrm{Units} / \mathrm{mg}$ protein $/ \mathrm{min}$. ( $p<0.01$ versus the $\mathrm{HI}-37^{\circ} \mathrm{C}$ group).

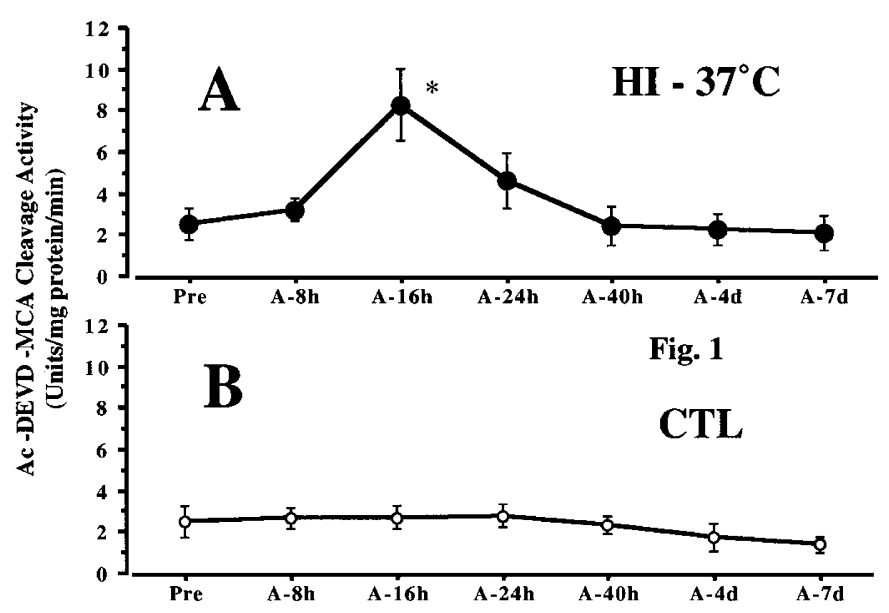

Figure 2. Changes in Ac-DEVD-MCA cleavage activity (Units/mg protein/ min, mean $\pm \mathrm{SD})$ in the ipsilateral hippocampus after HI $(A)$ or CTL $(B)$. For the $\mathrm{HI}-37^{\circ} \mathrm{C}$ group, the activity peaked at $16 \mathrm{~h}$ after insult and promptly decreased to baseline by $40 \mathrm{~h}$. In the CTL group, very little alteration in activity was observed. ${ }^{*} p<0.01$ vs Pre $\mathrm{HI}-37^{\circ} \mathrm{C}$ and all CTL time points (Fisher's test, ANOVA). $n=9$ for each time point. $H I-37^{\circ} \mathrm{C}$, hypoxia $(1 \mathrm{~h})$ and ischemia at normothermia $\left(37^{\circ} \mathrm{C}\right) ; C T L$, sham-operated control; Pre, preloading; $A-8 h$ to $A-7 d, 8 \mathrm{~h}$ to $7 \mathrm{~d}$ after HI insult. 
Table 1. Effect of systemic hypothermia and caspase inhibitor on caspase-3 activity in hippocampal lysates

\begin{tabular}{cccccc}
\hline & $\mathrm{CTL}$ & $\mathrm{HI}-37^{\circ} \mathrm{C}$ & $\mathrm{HI}-37^{\circ} \mathrm{C}+\mathrm{BAF}$ & $\mathrm{HI}-29^{\circ} \mathrm{C}$ & $\mathrm{HI}-29^{\circ} \mathrm{C}+\mathrm{BAF}$ \\
\hline $\begin{array}{c}\text { Caspase-3 activity at } 16 \mathrm{~h} \\
\text { (Units/mg protein/min) }\end{array}$ & $2.74 \pm 0.56$ & $8.32 \pm 1.72^{*}$ & $3.88 \pm 0.41 \dagger$ & $4.62 \pm 0.23 \dagger+$ & $2.65 \pm 0.37 \dagger \S$ \\
\hline
\end{tabular}

Representative data from nine samples per each subgroup $(n=9)$ are presented (mean $\pm \mathrm{SD})$.

Caspase-3 activity was determined at $16 \mathrm{~h}$ after HI insult by the Ac-DEVD-MCA cleavage method as described in "Materials and Methods."

$* p<0.01 v s$. CTL (Fisher's test, ANOVA).

$\dagger p<0.01$ vs. HI- $37^{\circ} \mathrm{C}$.

$\ddagger p<0.05$ vs. CTL (Fisher's test, ANOVA).

$\S p<0.05 v s$. HI- $37^{\circ} \mathrm{C}+\mathrm{BAF}$ or $\mathrm{HI}-29^{\circ} \mathrm{C}$.

In the combination treatment group with systemic hypothermia and BAF administration, caspase activity was significantly reduced to $2.65 \pm 0.37 \mathrm{Units} / \mathrm{mg}$ protein $/ \mathrm{min}$, which was lower than any of the other groups $\left(p<0.01\right.$ versus $\mathrm{HI}-37^{\circ} \mathrm{C}, p<$ 0.05 versus $\mathrm{HI}-37^{\circ} \mathrm{C}+\mathrm{BAF}$, and $\mathrm{HI}-29^{\circ} \mathrm{C}$ ).

Assessment of neuronal damage. The macroscopic appearance of the brain in the $\mathrm{HI}-37^{\circ} \mathrm{C}$ group consisted of only reduction of hippocampal volume and density of the ipsilateral hemisphere ( $p<0.05$ versus CTL, data not shown). The brain structure as a whole was relatively maintained; thus, this method was determined to produce mild brain damage. According to microscopic images of the CA1 pyramidal region in the ipsilateral hippocampus (figures not shown), the neuronal cell layer was irregular, and the cell density was obviously decreased in the $\mathrm{HI}-37^{\circ} \mathrm{C}$ group compared with the CTL group. However, few pyknotic cells, which are characteristic of apoptosis, were observed $7 \mathrm{~d}$ after $\mathrm{HI}$ insult. In some samples, apoptotic cell changes were scattered in the pyramidal cell layers 3-4 d after insult (data not shown), but pyknotic cells disappeared before PD 14. This suggests that neuronal cell death in the hippocampal CA1 region is related to apoptosis, but that this apoptotic change is mild and transient, and undetectable on PD 14 in this model.

In the presence of systemic hypothermia or BAF, the neurodegeneration of CA1 neurons was decreased. The disturbance of the pyramidal cell layer was decreased, and the cell density and volume of the ipsilateral hippocampus were maintained. In the presence of combined treatment with systemic hypothermia and BAF, pyramidal cells appeared unaffected by the HI insult.

CA1 neuronal cell count. The mean number of neuronal cells per field in the $\mathrm{HI}-37^{\circ} \mathrm{C}$ group was decreased significantly to $55.2(62.9 \%)$ compared with CTL at 87.7 (100\%) (Fig. 3). With BAF treatment, the cell number was maintained at 72.5 $(82.7 \%)\left(p<0.01\right.$ versus the HI- $37^{\circ} \mathrm{C}$ group). Systemic hypothermia at $29^{\circ} \mathrm{C}$ also decreased the loss of neuronal cells with $69.0(78.7 \%$ ) cells surviving ( $p<0.01$ versus the HI$37^{\circ} \mathrm{C}$ group). The combination of systemic hypothermia and BAF administration prevented neuronal damage even more, with $83.4(95.2 \%)$ cells surviving ( $p<0.01$ versus the HI$37^{\circ} \mathrm{C}, p<0.05$ versus the $\mathrm{HI}-37^{\circ} \mathrm{C}+\mathrm{BAF}$, and the $\mathrm{HI}-29^{\circ} \mathrm{C}$ group). The combination effect was confirmed in the histologic assessment.

In the VEH group, after the loss of a small number of cells, $82.6(94.1 \%)$ cells were maintained. Thus, the neuronal damage associated with the procedure itself was minimal.

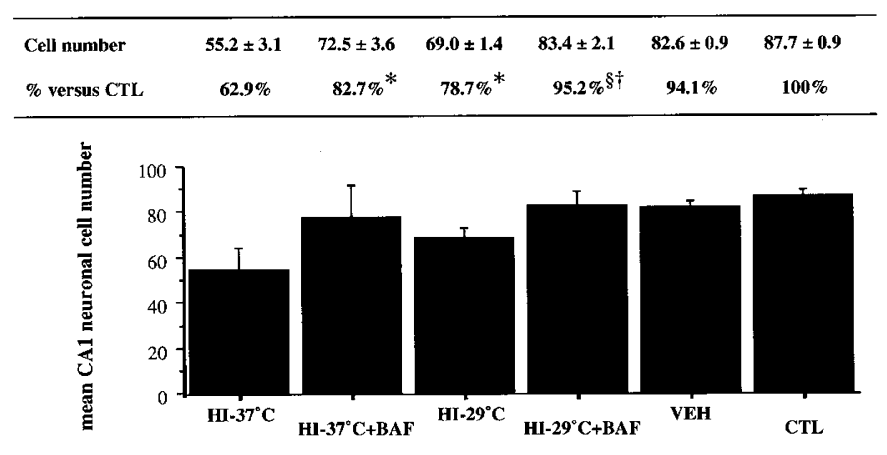

Figure 3. Quantification of the number of neuronal cells (PD 14) remaining in the ipsilateral hippocampal CA1 region after $\mathrm{HI}$ insult, and the effect of systemic hypothermia and caspase inhibitor (mean cell count per 400x magnification field, mean $\pm \mathrm{SD}$ ). $H I-37^{\circ} \mathrm{C}+B A F$, hypoxia and ischemia after preconditioning with BAF (100 nmol); VEH, vehicle (PBS) without HI; CTL, sham-operated control. ${ }^{*} p<0.05, \S p<0.01$ vs $\mathrm{HI}-37^{\circ} \mathrm{C} . \dagger p<0.05$ vs $\mathrm{HI}-37^{\circ} \mathrm{C}+\mathrm{BAF}$ or $\mathrm{HI}-29^{\circ} \mathrm{C}$ (Fisher's test, ANOVA). $n=6$ per subgroup.

Expression of DNA fragmentation. The time course for the expression of fragmented DNA (f-DNA) is presented in Figure 4. Within $24 \mathrm{~h}$ after insult, a smear pattern was detected. The smear pattern indicates the existence of various lengths of DNA and is associated with necrosis. The OD of DNA ladder bands increased gradually, becoming most prominent at 3-5 d after insult. The density then decreased by $7 \mathrm{~d}$ after insult. f-DNA was not observed in samples from the contralateral hippocampus (data not shown).

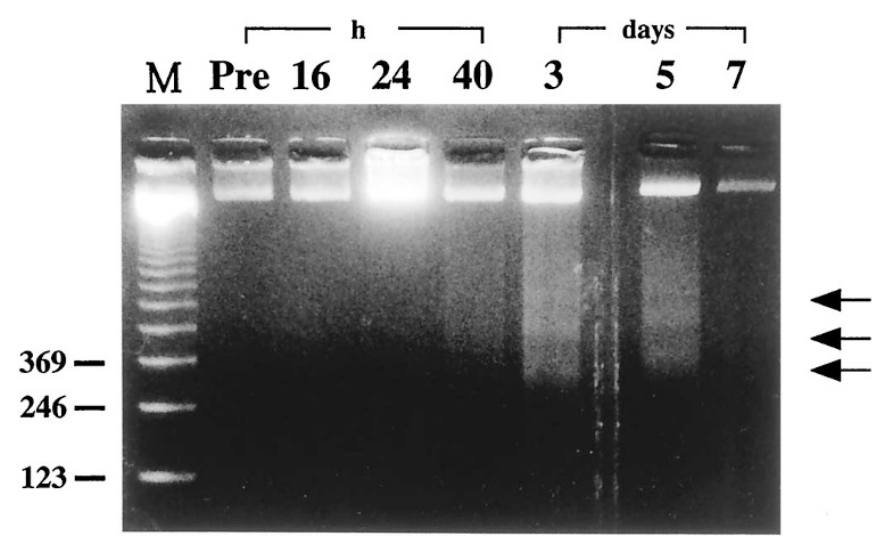

Figure 4. Change in the expression of fragmented DNA after HI insult. Samples in each lane consist of lysate from the ipsilateral hippocampus from three pups killed at $0,16,24$, and $40 \mathrm{~h}$, and 3, 5, and $7 \mathrm{~d}$ after insult. In the acute phase after the insult $(<24 \mathrm{~h})$, only smear patterns are observed. In the delayed phase ( $40 \mathrm{~h}$ to $7 \mathrm{~d}$ ), DNA ladder bands are detected, peaking at 3-5 d (PD 10-12) after insult. Experiments were performed three times with different samples. $M$, DNA marker (123 bp). 
Effect of systemic hypothermia and caspase inhibitor administration on DNA fragmentation. The effect of systemic hypothermia and BAF on DNA fragmentation $4 \mathrm{~d}$ after $\mathrm{HI}$ insult (PD 11) is shown in Figure 5. In the $\mathrm{HI}-37^{\circ} \mathrm{C}$ group, f-DNA was detected as a ladder of bands mixed with the smear pattern, reflecting dominance of necrosis. With the administration of systemic hypothermia or BAF, f-DNA was significantly decreased, and the smear density was decreased as well. In the presence of hypothermia and BAF in combination, furthermore, neither f-DNA nor the smear pattern of DNA were observed.

\section{DISCUSSION}

Numerous reports have focused on the characteristic features of DNCD observed in specific regions of animal brains after transient HI, including the hippocampus, and striatum (1-4). These features are similar to the morphologic changes observed in apoptosis, although they do not appear to be the same phenomenon. The correlation between apoptosis and hypoxicischemic brain damage remains inconclusive. In the present study, the following findings were shown.

DNCD was observed in a mild HI model prepared according to a modified Rice's procedure of left carotid artery ligation and $8 \%$ hypoxia for $1 \mathrm{~h}$. In this model, brain damage was relatively mild, and severe damage (e.g. infarction) due to necrosis did not occur. The occurrence of DNCD was confirmed with three procedures, which consisted of histologic, enzymatic, and molecular methods. Histologic assessment revealed that at 3-4 d after insult, basophilic and pyknotic cells, which are characteristic of apoptosis, were scattered in several regions, but little severe damage (e.g. infarction) indicative of necrosis was observed. Pyknotic cells disappeared and at $7 \mathrm{~d}$ after insult (PD 14) mild neurodegeneration was observed,

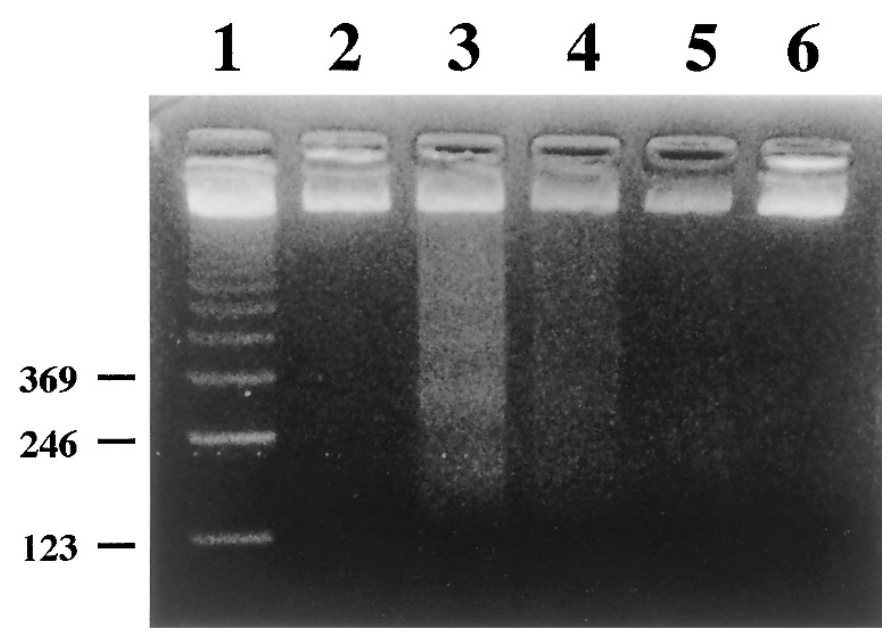

Figure 5. Effect of systemic hypothermia and BAF administration on DNA fragmentation after HI insult (PD 11). In the ipsilateral hippocampus of the $\mathrm{HI}-37^{\circ} \mathrm{C}$ group, DNA ladder bands are observed on the smear pattern, indicating the presence of apoptosis as well as necrosis. With BAF, and systemic hypothermia at $29^{\circ} \mathrm{C}$, fragmented DNA is significantly decreased (Lanes 4, 5), but the OD of the smear patterns is also reduced. Experiments were performed three times with different samples. Lane 1: DNA marker (123 bp), Lane 2: sham-operated control, Lane 3: $\mathrm{HI}-37^{\circ} \mathrm{C}$, Lane $4: \mathrm{HI}-37^{\circ} \mathrm{C}+\mathrm{BAF}$, Lane 5: $\mathrm{HI}-29^{\circ} \mathrm{C}$, Lane 6: $\mathrm{HI}-29^{\circ} \mathrm{C}+\mathrm{BAF}$. consisting of volume loss in the ipsilateral hippocampus, disturbance of the pyramidal cell layer, and a decrease in cell density in the hippocampal CA1 region. From these results, we suggest that some aspects of the mild neurodegeneration observed in this model mainly depend on apoptotic cell death. In recent reports, a family of caspases has been shown to play a key role in apoptosis, and the delayed expression of caspase-3, a terminal player in the apoptotic cascade, has been detected in vivo. The expression of caspase-3 after global ischemia (17) or after $2 \mathrm{~h}$ of HI (Levine's procedure) (19) peaks $24-72 \mathrm{~h}$ after insult. This delayed expression may have a protective effect against delayed brain damage. Indeed, the administration of a caspase inhibitor $3 \mathrm{~h}$ after insult afforded neuroprotection against HI brain injury (19). In the present study, caspase-3 cleavage activity peaked $16 \mathrm{~h}$ after $\mathrm{HI}$ insult and quickly decreased to the baseline level by $40 \mathrm{~h}$. This result indicates that the expression of caspase-3 after mild $\mathrm{HI}$ insult is more transient and occurs earlier than that previously reported after severe HI insult $(17,19)$, and suggests that the delayed administration of caspase inhibitors may be effective only when given immediately after insult. DNA electrophoresis revealed f-DNA ladder bands in samples from the ipsilateral hippocampus after HI insult. In the present study, f-DNA was first detected at $24 \mathrm{~h}$, peaked in 3-5 d, and gradually became undetectable (Fig. 4). Ladder bands were visualized over the smear pattern.

In this study, the neuroprotective effects of systemic hypothermia and caspase inhibitor administration were assessed against brain damage induced by HI. Systemic hypothermia has been described as effective against brain damage caused by global ischemia and traumatic injury. Previous reports have stated that mild or moderate hypothermia $\left(30-34^{\circ} \mathrm{C}\right)$ is useful for damage reduction $(24,26,28,32)$. In particular, mild hypothermia decreases brain damage in the cortex and hippocampus (28-32). But most of these studies were limited to histologic investigations. Recently, the effect of intra-ischemic hypothermia on DNA fragmentation was recognized in the rat brain after global ischemia (25). However, no biochemical assays were performed to assess the underlying mechanisms of the brain damage. In the present study, we introduced moderate systemic hypothermia at $29^{\circ} \mathrm{C}$. The rectal temperature of $30^{\circ} \mathrm{C}$ during hypoxia was achieved immediately $(p<0.01$ versus normothermia, data not shown). This hypothermia prevented neuronal cell loss and effected a reduction of caspase-3 activity, which has not been described previously. These results suggest that hypothermic neuroprotection is accompanied by a reduction in caspase activity, indicating an inhibition of apoptosis, even though neuronal damage associated with tissue temperature has in the past been attributed mainly to necrosis. However, given the fact that hypothermia only widened the therapeutic window and prolonged or delayed the onset of damage, whether the peak of caspase- 3 in the $\mathrm{HI}-29^{\circ} \mathrm{C}$ is at $16 \mathrm{~h}$ or later is unknown in this study and is now being investigated. In the present study, intracerebroventricular injection of BAF before insult was used to protect hippocampal neurons from the effects of HI. Injection of BAF reduced caspase-3 activity significantly, which resulted in the protection of neuronal cells in the CA1 region. Chen et al. reported 
that BAF exerts a neuroprotective effect when administered systemically as well, because of its lipophilic nature (19). If systemic administration has the same effect as intraventricular injection, BAF could be administered easily. Because the induction of caspases is delayed relative to $\mathrm{HI}$ insult, the presence of caspase inhibitors may provide a therapeutic window for neuroprotection. In this respect, further investigations are required to establish the specifics of treatment of hypoxicischemic brain injury with caspase inhibitors.

The combinatorial effect of systemic hypothermia and caspase inhibitor against brain damage induced by HI shows that caspase-3 activity at $16 \mathrm{~h}$ was reduced significantly and synergistically (Table 1). In addition, hippocampal neuronal cells in the CA1 region were also protected, and $95.2 \%$ of the cells were maintained. Whereas previous reports have described the individual protective effects of hypothermia and caspase inhibitors against brain damage, no synergistic effects have been reported. In the present study, we detected the synergistic effect of systemic hypothermia and caspase inhibitor. The results of this study indicate that this combination resulted in neuroprotection against both apoptotic and necrotic cell death. In this respect, combined therapy with these two agents may provide a therapeutic window for the prevention of $\mathrm{HI}$ insult effects in the developing brain and may be applicable to daily clinical situations in the future.

\section{REFERENCES}

1. Bruck Y, Bruck W, Kretzschmer HA, Lassmann H 1996 Evidence for neuronal apoptosis in pontosubicular neuron necrosis. Neuropathol Appl Neurobiol 22:23-29

2. Pulsinelli WA, Brierley JB, Plum F 1982 Temporal profile of neuronal damage in a model of transient forebrain ischemia. Ann Neurol 11:491-498

3. Linnik MD, Zobrist RH, Hatfield MD 1993 Evidence supporting a role for programmed cell death in focal cerebral ischemia in rats. Stroke 24:2002-2008

4. Pettmann B, Henderson CE 1998 Neuronal cell death. Neuron 20:633-647

5. Beilharz EJ, Williams CE, Dragunow M, Sirimanne ES, Gluckman PD 1995 Mechanisms of delayed cell death following hypoxic-ischemic injury in the immature rat: evidence for apoptosis during selective neuronal loss. Brain Res Mol Brain Res 29:1-14

6. Tominaga T, Kure S, Narisawa K, Yoshimoto T 1993 Endonuclease activation following focal ischemic injury in the rat brain. Brain Res 608:21-26

7. Pravdenkova SV, Basnakian AG, Jill SJ, Andersen BJ 1996 DNA fragmentation and nuclear endonuclease activity in rat brain after severe closed head injury. Brain Res 729:151-155

8. Rink A, Fung KM, Trojanowski JQ, Lee VM, Neugebauer E, McIntosh TK 1995 Evidence of apoptotic cell death after experimental traumatic brain injury in the rat. J Pathol 147:1575-1583

9. Cotman CW, Anderson AJ 1995 A potential role for apoptosis in neurodegeneration and Alzheimer's disease. Mol Neurobiol 10:19-45

10. Mitchell IJ, Lawson S, Moser B, Laidlaw SM, Cooper AJ, Walkinshaw G, Waters CM 1995 Glutamate-induced apoptosis results in a loss of striatal neurons in the Parkinsonian rat. Neuroscience 63:1-5

11. Portera-Cailliau C, Hedreen JC, Price DL, Koliatsos VE 1995 Evidence for apoptotic cell death in Huntington's disease and excitotoxic animal models. J Neurosci 15:3775-3787
12. Thomas BL, Gates DJ, Richfield EK, O’Brian TF, Schweitzer JB, Steindler DA 1995 DNA end labeling (TUNEL) in Huntington's disease and other neuropathological conditions. Exp Neurol 133:265-272

13. Braun JS, Novak R, Herzog KH, Bodner SM, Cleveland JL, Tuomanen EI 1999 Neuroprotection by a caspase inhibitor in acute bacterial meningitis. Nat Med 5:298-302

14. Montgomery EME, Bardgett ME, Lall B, Csernansky CA, Csernansky JG 1999 Delayed neuronal loss after administration of intracerebroventricular kainic acid to preweanling rats. Brain Res Dev Brain Res 112:107-116

15. Kondratyev A, Gale K 2000 Intracerebral injection of caspase-3 inhibitor prevents neuronal apoptosis after kainic acid-evoked status epilepticus. Brain Res Mol Brain Res 75:216-224

16. Pollard H, Chantagrel S, Charriaut-Marlangue C, Moreau J, Ben-Ari Y 1994 Apoptosis associated DNA fragmentation in epileptic brain damage. Neuroreport 5:10531055

17. Chen J, Nagayama T, Jin K, Stetler RA, Zhu RL, Graham SH, Simon RP 1998 Induction of caspase-3-like protease may mediate delayed neuronal death in the hippocampus after transient cerebral ischemia. J Neurosci 18:4914-4928

18. Gillardon F, Bottiger B, Schmits B, Zimmermann M, Hossmann KA 1997 Activation of CPP-32 protease in hippocampal neurons following ischemia and epilepsy. Brain Res Mol Brain Res 50:16-22

19. Cheng Y, Deshmukh M, D'Costa A, Demaro JA, Gidday JM, Shah A, Sun Y, Jacquin MF, Johnson EM, Holtzman DM 1998 Caspase inhibitor affords neuroprotection with delayed administration in a rat model of neonatal hypoxic- ischemic brain injury. J Clin Invest 101:1992-1999

20. Fink K, Zhu J, Namura S, Shimizu-Sasamata M, Endres M, Ma J, Dalkara T, Yuan J, Moskowitz MA 1998 Prolonged therapeutic window for ischemic brain damage caused by delayed caspase activation. J Cereb Blood Flow Metab 18:1071-1076

21. Deshmukh M, Vasilakos J, Deckwerth TL, Lampe PA, Shivers BD, Johnson EM Jr 1996 Genetic and metabolic status of NGF-derived sympathetic neurons saved by an inhibitor of ICE family proteases. J Cell Biol 135:1341-1345

22. Himi T, Ishizaki Y, Murota S 1998 A caspase inhibitor blocks ischaemia-induced delayed neuronal death in the gerbil. Eur J Neurosci 10:777-781

23. Ferrand-Drake M, Wieloch T 1999 The time course of DNA fragmentation in the choroid plexus and the CA1 region following transient global ischemia in the rat brain. The effect of intra-ischemic hypothermia. Neuroscience 93:537-549

24. Dietrich WD, Busto R, Alonson O, Globus MY-T, Ginsberg MD 1993 Intraischemic but not postischemic brain hypothermia protects chronically following global forebrain ischemia in rats. J Cereb Blood Flow Metab 13:541-549

25. Busto R, Dietrich WD, Globus MY-T 1987 Small differences in intraischemic brain temperature critically determine the extent of ischemic neuronal injury. J Cereb Blood Flow Metab 7:729-738

26. Minamisawa H, Nordstrom CH, Smith ML, Siesjo BK 1990 The influence of mild body and brain hypothermia on ischemic brain damage. J Cereb Blood Flow Metab 10:365-374

27. Welsh FA, Harris VA 1991 Postischemic hypothermia fails to reduce ischemic injury in gerbil hippocampus. J Cereb Blood Flow Metab 11:617-620

28. Laptook AR, Corbett RJT, Sterett R, Burns DK, Tollefsbol G, Garcia D 1994 Modest hypothermia provides partial neuroprotection for ischemic neonatal brain. Pediatr Res 35:436-442

29. Saeed D, Goetzman BW, Gospe SM 1993 Brain injury and protective effects of hypothermia using triphenyltetrazolium chloride in neonatal rat. Pediatr Neurol 9:263-267

30. Towfighi J, Housman C, Heitjan DF, Vannucci RC, Yager JY 1994 The effect of focal cerebral cooling on perinatal hypoxic-ischemic brain damage. Acta Neuropathol (Berl) 87:598-604

31. Yager JY, Towfighi J, Vannucci RC 1993 Influence of mild hypothermia on hypoxicischemic brain damage in the immature rat. Pediatr Res 34:525-529

32. Bona E, Hagberg H, Loberg EM, Bagenholm R, Thoresen M 1998 Protective effects of moderate hypothermia after neonatal hypoxia-ischemia: short- and long-term outcome. Pediatr Res 43:738-745

33. Morita T, Kato H, Iwanaga S, Takada K, Kimura T, Sakakibara S 1977 New fluorogenic substrates for $\alpha$-thrombin, factor Xa, kallikreins, and urokinase. J Biochem 82:1495-1498

34. Rice JE, Vanucci RC, Brierley JB 1981 The influence of immaturity on hypoxicischemic brain damage in the rat. Ann Neurol 9:131-141

35. Cheng Y, Gidday JM, Yan Q, Shah AR, Holtzman DM 1997 Marked age-dependent neuroprotection by BDNF against neonatal hypoxic-ischemic brain injury. Ann Neurol 41:521-529 